\title{
Plate reconstructions and tomography reveal a fossil lower mantle slab below the Tasman Sea
}

\author{
W.P. Schellart ${ }^{\text {a,b,* }}$, B.L.N. Kennett ${ }^{\text {a }}$, W. Spakman ${ }^{\text {c }}$, M. Amaru ${ }^{\text {c,1 }}$ \\ a Research School of Earth Sciences, The Australian National University, Canberra, ACT 0200, Australia \\ b School of Geosciences, Monash University, Melbourne, VIC 3800, Australia \\ c Department of Earth Sciences, Utrecht University, Utrecht, The Netherlands
}

\section{A R T I C L E I N F O}

\section{Article history:}

Received 14 March 2008

Received in revised form 7 October 2008

Accepted 1 November 2008

Available online 24 January 2009

Editor: C.P. Jaupart

\section{Keywords:}

mantle tomography

plate reconstructions

subduction

slab detachment

Southwest Pacific

New Caledonia

New Zealand

obduction

mantle viscosity

\begin{abstract}
A B S T R A C T
The Southwest Pacific region is tectonically complex and is home to numerous fossil and active subduction zones. At the Earth's surface, there remains a geological controversy regarding the polarity and continuity of fossil subduction zones in New Zealand and New Caledonia, the origin of obducted ophiolites, the presence of high-pressure metamorphism, the occurrence of widespread Cenozoic magmatism, and the potential disappearance of one or more ocean basins. This controversy can be solved by looking at the lower mantle rather then at the Earth's surface. New P-wave and S-wave mantle tomography models from the Southwest Pacific are presented, which identify a previously unrecognized lower-mantle high-velocity anomaly that cannot be linked to Pacific subduction. The anomaly is located below the Tasman Sea at $\sim 1100 \mathrm{~km}$ depth, strikes NW-SE and is $\sim 2200 \mathrm{~km}$ by $600-900 \mathrm{~km}$ in lateral extent. By combining relative and absolute plate motions it is demonstrated that when the geological structures at the surface are reinterpreted as a single northeast-dipping 2500-km middle Cenozoic subduction zone (the so-called New Caledonia subduction zone) the lower mantle anomaly can be accounted for, as it is found at the predicted location and depth. Discovery of the lower mantle slab anomaly thereby solves a long-standing geological controversy in the New Zealand-New Caledonia region. Finally, reconstructions and analytical calculations predict a lower mantle slab sinking velocity of $\sim 1.5 \mathrm{~cm} / \mathrm{yr}$ and a lower mantle viscosity of $\sim 10^{22} \mathrm{~Pa} \cdot \mathrm{s}$.
\end{abstract}

(c) 2008 Elsevier B.V. All rights reserved.

\section{Introduction}

The geodynamic processes responsible for widespread Tertiary magmatism, crustal deformation, high-pressure metamorphism, and emplacement of two massive ophiolite sheets (surface area of $\sim 3.5 \times 10^{4} \mathrm{~km}^{2}$ and $\geq 3 \times 10^{4} \mathrm{~km}^{2}$ ) in Northland (New Zealand) and New Caledonia (Fig. 1) are controversial. The geology of the two regions was interpreted as resulting from two separate subduction zones, a northeast-dipping subduction zone in New Caledonia (Regnier, 1988; Aitchison et al., 1995; Cluzel et al., 2001; Spandler et al., 2005; Baldwin et al., 2007) and a southwest-dipping subduction zone (Malpas et al., 1992; Herzer, 1995; Hayward et al., 2001; Whattam et al., 2004; Mortimer et al., 2007) or northwest-dipping subduction zone (Brothers, 1984; Kamp, 1984) in Northland. However, such local models involving opposite-dipping slabs cannot be integrated into a unifying tectonic model for the entire Southwest Pacific (Schellart et al., 2006; Schellart, 2007). In New Caledonia, evidence for northeastdirected subduction is strong, including an Eocene volcanic arc

\footnotetext{
* Corresponding author. School of Geosciences, Monash University, Melbourne, VIC 3800, Australia. Tel.: +61 39905 1782; fax: +61 399054903.

E-mail address: wouter.schellart@sci.monash.edu.au (W.P. Schellart).

${ }^{1}$ Now at: Chevron Energy Technology Company, Houston, Texas, USA.
}

(Loyalty arc) (Aitchison et al., 1995; Crawford et al., 2003), subduction-induced high-pressure metamorphism (Cluzel et al., 2001; Spandler et al., 2005), fore-arc boninites in the ophiolite (Crawford et al., 2003), a north-dipping low velocity zone below New Caledonia and a gravity-low along the west coast of New Caledonia (Regnier, 1988).

In Northland, southwest or northwest-directed subduction models fail to meet several geological, geophysical and spatio-temporal constraints (Schellart, 2007). For example, geological and geophysical investigations do not show any evidence of a fossil trench or accretionary wedge to the northeast of Northland. For further details and descriptions of additional constraints please see Schellart (2007). It is found that Early Miocene volcanism in the Northland region is better explained with a northeast-dipping slab. In between New Caledonia and Northland, the Three Kings Ridge has been explained by west or east-dipping subduction, but recently recovered fore-arc boninites (Mortimer et al., 2007) and high-pressure metamorphic rocks (Meffre et al., 2006) from the western slope of the ridge support the latter interpretation.

A new hypothesis proposes the former existence of a 83-55 Ma backarc basin (South Loyalty Basin) to the east of the Norfolk-New Caledonia Ridge and to the north of the New Zealand region, which subducted along a single northeast-dipping subduction zone (Crawford et al., 2003; Schellart et al., 2006; Schellart, 2007), the so- 


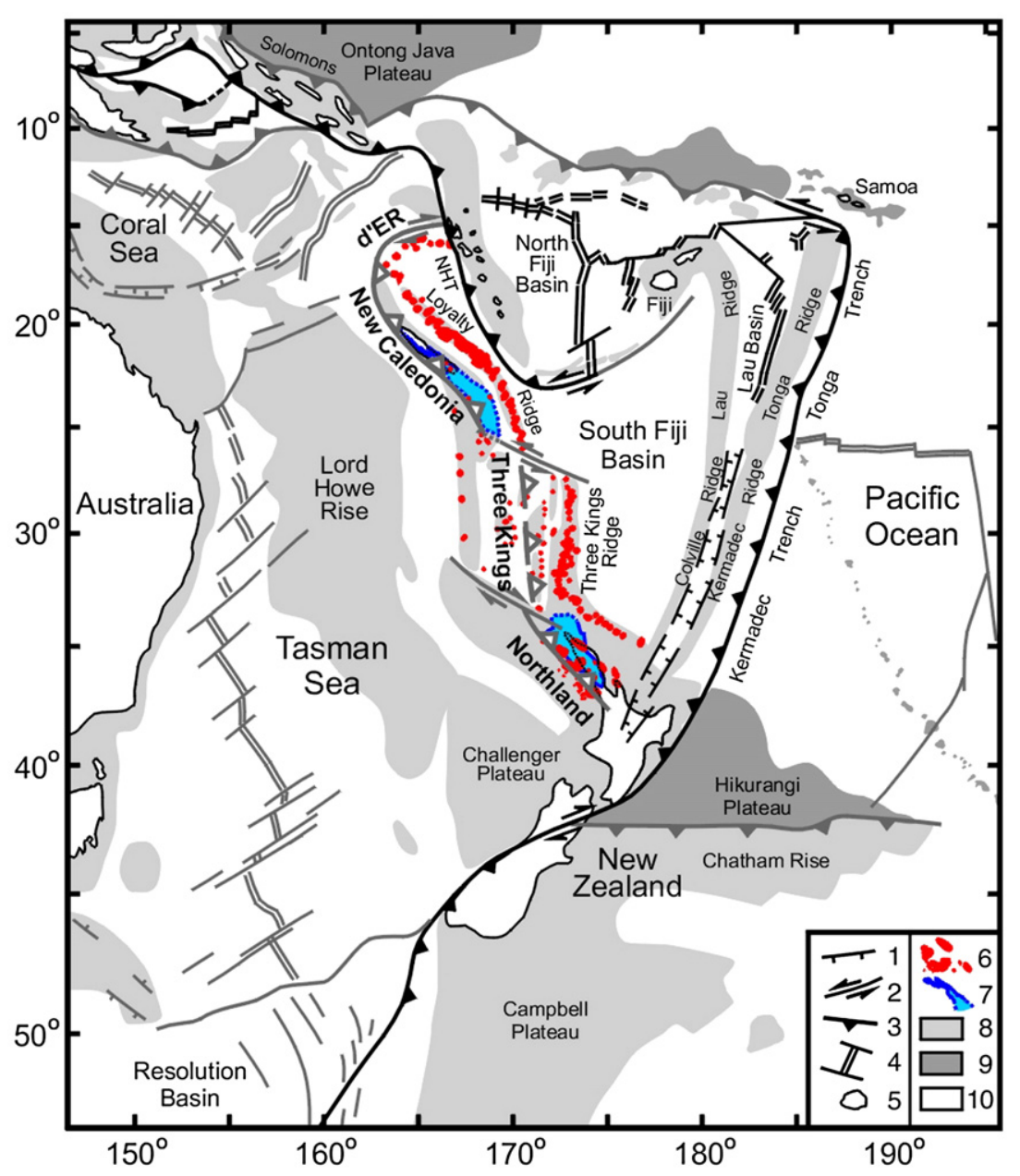

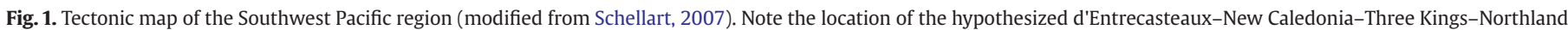

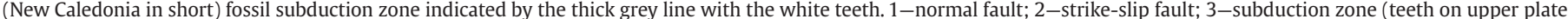

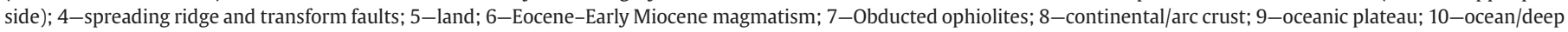
sea basin floor. d'ER-d'Entrecasteaux Ridge; NHT-New Hebrides Trench.

called New Caledonia subduction zone (Fig. 1). The terminal stage of subduction is hypothesized to be responsible for widespread magmatism and southwest-directed ophiolite obduction in New Caledonia and Northland (Schellart, 2007). Calculations from relative plate motions imply that subduction along the New Caledonia subduction zone started at 50 and $40 \mathrm{Ma}( \pm 5 \mathrm{Ma})$ in the north and south, respectively (Schellart, 2007). Subduction amounted to a maximum of 1100,600 and $500 \mathrm{~km}$ in the New Caledonia, Three Kings and Northland regions, respectively, as implied by the original geometry of the South Loyalty Basin (Schellart et al., 2006). Schellart (2007) proposed that the New Caledonia slab detached in the final stage of subduction and that the timing of detachment could be constrained by the timing of obduction and timing of magmatism. Assuming that obduction is largely controlled by slab pull forces, and assuming that certain magmatism in Northland, New Caledonia and the Norfolk basin is detachment-induced, then the timing of detachment has to be after the timing of obduction and before the timing of detachment-induced magmatism. The time of detachment was simply assumed to be right in between these two geological events. As such, the time of detachment is estimated at 30, 27 and $24 \mathrm{Ma}( \pm 3 \mathrm{Ma})$ in southern New Caledonia, the Norfolk basin and northwest Northland, respectively (Schellart, 2007). The timing suggests that slab detachment started in the north and migrated southward along a sub-horizontal tear, comparable to detachment models proposed for the Mediterranean and Tethyan subduction zones (Wortel and Spakman, 2000; Hafkenscheid et al., 2006).
Here we test the new hypothesis by coupling the regional reconstructions to two lower mantle hotspot reference frames. This allows us to make predictions regarding the current geographical location and depth of the fossil slab in the mantle. Analytical calculations provide an additional estimate for the current depth of the slab anomaly. The reconstructions predict that subduction of the South Loyalty Basin lithosphere lasted from $\sim 50$ Ma until $\sim 25 \mathrm{Ma}$, that the slab during this subduction period was 20 to $60 \mathrm{Myr}$ old and thereby 50-87 km thick (Schellart, 2007). As discussed in Cloos (1993), oceanic lithosphere as young as $10 \mathrm{Ma}$ is already neutrally buoyant with respect to the underlying asthenosphere, so 20-60 Myr old oceanic lithosphere should readily subduct, more so if the crust becomes progressively eclogitized, and detach at the final stage of subduction, and should most likely be visible as a high-velocity anomaly in mantle tomography models. Results from an S-wave tomography model and a new P-wave tomography model will be presented, indeed showing a high-velocity anomaly at the predicted location and depth to represent the fossil slab that subducted along the New Caledonia subduction zone.

\section{Predictions from reconstructions}

Reconstructions of subduction zone migration can predict the location of fossil slabs when combined with the timing of slab detachment, predicted slab-sinking patterns and sinking velocities. Fig. 2 shows the migration of the New Caledonia fossil subduction 
zone from 48 Ma to Present from combining subduction zone migration relative to Australia (Schellart et al., 2006; Schellart, 2007) and motion of the Australian plate with respect to two hotspot reference frames (Gordon and Jurdy, 1986; Müller et al., 1993). The reconstructions thereby constrain subduction zone migration relative to a lower mantle reference frame. Fig. 2 also shows the timing of termination of subduction zone activity and slab detachment as deduced from Schellart (2007). Prior to slab detachment, west-directed trench retreat along the New Caledonia subduction zone resulted primarily from slab rollback, while the northward motion of the trench resulted from the northward motion of the Australian plate to which the South Loyalty slab was still attached. After slab detachment, which occurred at $30 \mathrm{Ma}$ in the north and $\sim 24 \mathrm{Ma}$ in the south, the fossil trench was basically a passive feature that moved northward along with the $~$ northward motion of the Australian plate.

Fig. 3 provides a three-dimensional perspective of the progressive subduction, sinking and detachment of the South Loyalty slab from $48 \mathrm{Ma}$ to the Present. Subduction starts in the north (New Caledonia region, Fig. 3a) and progressively grows southward (Fig. 3b). At the final stage of subduction in the New Caledonia region a subhorizontal slab tear develops (Fig. 3c) that propagates southward (Fig. 3d), resulting in detachment and sinking of the South Loyalty slab into the mantle. When slab detachment is complete, the entire South Loyalty Basin slab sinks vertically into the mantle (Fig. 3e-f). The diagrams further show development of a sub-vertical slab tear at the northernmost part of the subduction zone (below the d'Entrecasteaux zone) that allows for efficient slab-rollback-induced toroidal upper mantle return flow from behind the slab towards the mantle wedge side (e.g. Schellart et al., 2007; Schellart, 2008), thereby facilitating rapid slab rollback at the northernmost part of the subduction zone.

Geodynamic models of progressive subduction can provide constraints on the sinking patterns of slabs in the mantle. Such sinking patterns are important to be able to determine the location of fossil slabs in the mantle. One can obtain an estimate of the sinking angle of upper mantle slabs from quantifying the degree of subduction partitioning, i.e. how much of the total subduction velocity $\left(v_{\mathrm{S}}\right)$ is due to the trench migration ( $v_{\mathrm{T}}$, trench retreat is positive) and how much is due to trenchward subducting plate motion $\left(v_{\mathrm{SP}}\right)$. Subduction partitioning can be expressed as: $v_{\mathrm{T}} / v_{\mathrm{S}}$. Laboratory models (e.g. Schellart, 2005, 2008) show that for $v_{\mathrm{T}} / v_{\mathrm{S}}>\sim 0.5$ the slab sinks backwards (oceanward), for $0 \leq v_{\mathrm{T}} / v_{\mathrm{S}}<0.5$ the slab sinks subvertical, and for $v_{\mathrm{T}} / v_{\mathrm{S}}<0$ the slab sinks forward (towards the overriding plate). Fig. 2 indicates that for the New Caledonia slab, some $50-75 \%$ of the total subduction rate is due to trench retreat $\left(v_{\mathrm{T}} / v_{\mathrm{S}}=0.50-0.75\right)$. 3D laboratory models of progressive subduction with a free trench show that when $v_{\mathrm{T}} / v_{\mathrm{S}}=0.50$ 0.75 , then slabs sink vertically $\left(90^{\circ}\right)$ to backward at angles of $70^{\circ}$ in the upper mantle (Schellart, 2005, 2008; see for example Fig. 4b, c in Schellart, 2005). One can thus expect that the South Loyalty slab would have sunk vertically downward to backward (west to southwestward) at $\sim 70^{\circ}$ during its descent in the upper mantle. Furthermore, lower-mantle slabs sink sub-vertically (Pysklywec et al., 2003; Schellart et al., 2007).

The NW-SE extent of the fossil slab is constrained by the width (trench-parallel extent) of the subduction zone (max. $2500 \mathrm{~km}$ ), while its NE-SW extent is constrained by the original size of the South Loyalty Basin (average of $750 \mathrm{~km}$ ) (Schellart et al., 2006). These geometrical constraints, in combination with the trench migration patterns (Fig. 2) and inferred sinking kinematics for the slab as deduced from geodynamic modelling indicate that the fossil South Loyalty slab is laterally confined by the green dashed line in Fig. 2.

The reconstructions further indicate that the subduction velocity is on average $\sim 6 \mathrm{~cm} / \mathrm{yr}(500-1100 \mathrm{~km}$ of subduction in 10-16 Myr), implying an upper mantle sinking velocity of similar magnitude (Schellart, 2005). Sinking velocities are thought to reduce by a factor of four upon entering the lower mantle (Lithgow-Bertelloni and Richards,
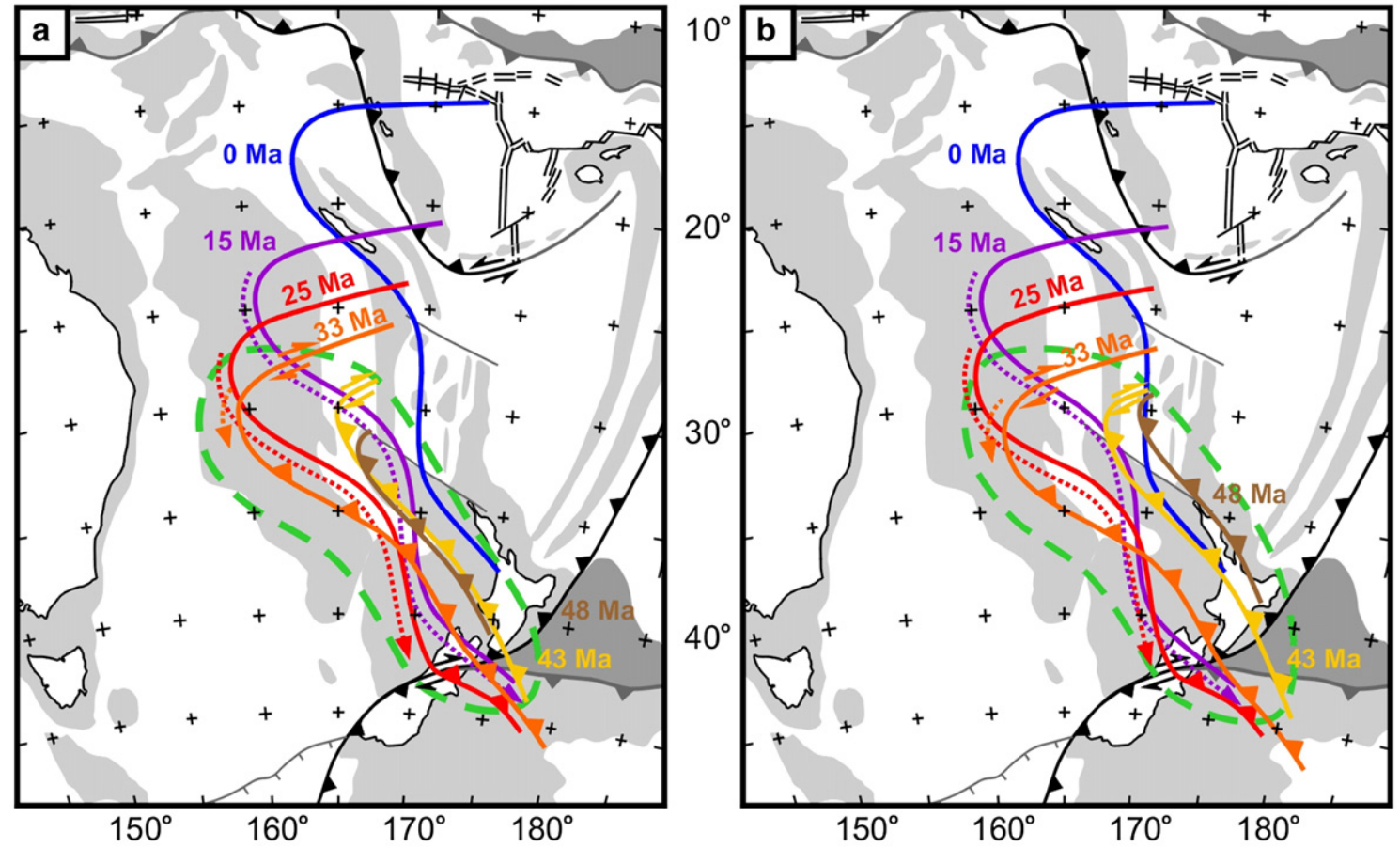

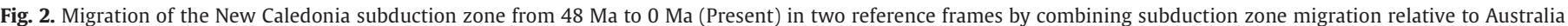

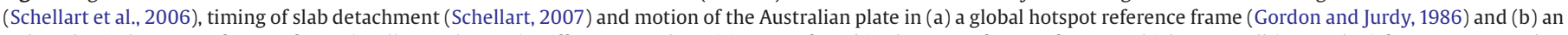

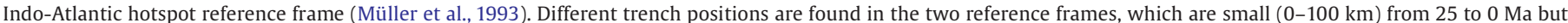

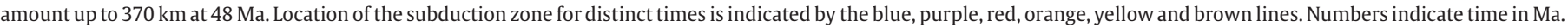

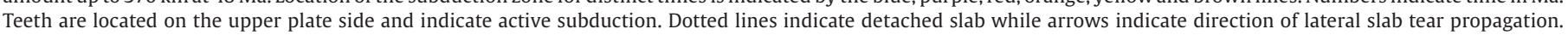
Dashed green line indicates predicted lateral extent of the detached South Loyalty slab. 

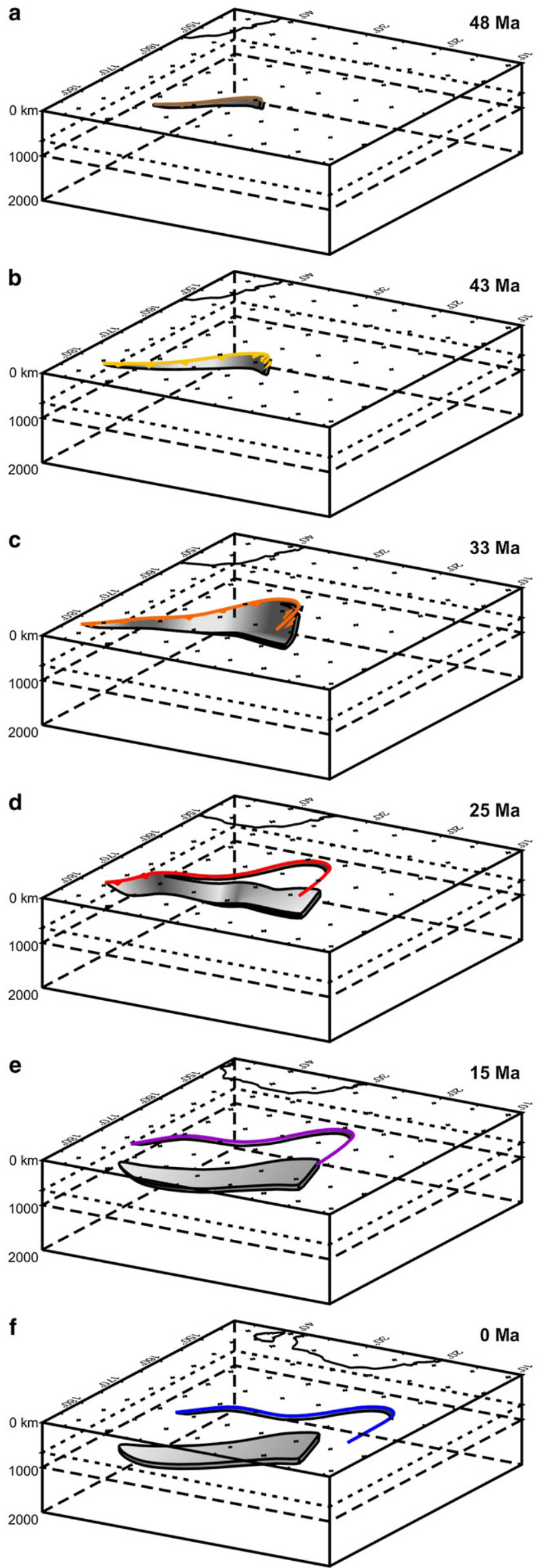

1998), suggesting a lower mantle sinking velocity of $\sim 1.5 \mathrm{~cm} / \mathrm{yr}$. The lower mantle sinking velocity can also be estimated by calculating the sinking velocity of an oblate ellipsoid $\left(V_{\mathrm{E}}\right)$ parallel to its shortest axis (Kerr and Lister, 1991), with $V_{\mathrm{E}}=\operatorname{Sg}\left(\rho_{\mathrm{S}}-\rho_{\mathrm{M}}\right) D^{2} / 18 \mu_{\mathrm{LM}}$. In the special case where the ellipsoid is a sphere, then $S=1$ and the equation is identical to the Stokes equation. Here, $S$ is the shape factor (Kerr and Lister, 1991) with $S \approx 0.37$ for the South Loyalty slab, $g$ is the gravitational acceleration $\left(9.8 \mathrm{~m} / \mathrm{s}^{2}\right),\left(\rho_{\mathrm{S}}-\rho_{\mathrm{M}}\right)$ is the density contrast between slab and mantle $\left(80 \mathrm{~kg} / \mathrm{m}^{3}\right), D=(a b c)^{1 / 3}, \mu_{\mathrm{LM}}$ is the lower mantle viscosity $\left(\sim 10^{22}\right.$ Pa.s), and $a, b$ and $c$ are the shortest $(\sim 70 \mathrm{~km})$, intermediate $(\sim 750 \mathrm{~km})$ and longest axis $(\sim 2500 \mathrm{~km})$ of the ellipsoid (detached South Loyalty slab), respectively. The calculations give $V_{\mathrm{E}} \approx 1.3 \mathrm{~cm} / \mathrm{yr}$, which is comparable to the lower mantle sinking velocity cited above.

One assumption that is incorporated into this calculation regards the density contrast between slab and mantle. This was previously investigated by Cloos (1993), who did calculations for oceanic lithosphere with a $7 \mathrm{~km}$ thick oceanic crust, of which the crust was eclogitized during subduction. Following these calculations, the density contrast between the South Loyalty slab with eclogitized crust (which was 20-60 Myr old at the time of subduction and $~ 50-$ $87 \mathrm{~km}$ thick) and the ambient upper mantle is then $\sim 78-84 \mathrm{~kg} / \mathrm{m}^{3}$. Considering that the upper mantle sinking velocity was relatively high $(\sim 6 \mathrm{~cm} / \mathrm{yr})$ and the time that the fossil slab has spent in the lower mantle (decreasing from an average of $30 \mathrm{Myr}$ in the north to an average of $20 \mathrm{Myr}$ in the south), it is expected that the slab has retained a large part of its thermal structure. So as a first-order approximation, a slab-mantle density contrast of $80 \mathrm{~kg} / \mathrm{m}^{3}$ for both the upper mantle and lower mantle appears reasonable.

With subduction starting at $\sim 50 \mathrm{Ma}$ in the north, slab detachment in New Caledonia at $~ 30 \mathrm{Ma}$, average upper and lower mantle sinking velocities of $6.0 \mathrm{~cm} / \mathrm{yr}$ and $1.5 \mathrm{~cm} / \mathrm{yr}$, and a transition zone at $670 \mathrm{~km}$, the slab tip and trailing edge of the slab would presently be at 1250 and $950 \mathrm{~km}$ depth, respectively. Along the Three Kings and Northland sections, subduction started at $\sim 45$ and $\sim 40 \mathrm{Ma}$ and detachment occurred at $\sim 27$ and $\sim 24 \mathrm{Ma}$, respectively. Thus, the slab tip and trailing edge would now have reached a depth of 1180 and $910 \mathrm{~km}$ (Three Kings), and 1100 and $860 \mathrm{~km}$ (Northland). Thus, we predict that the fossil South Loyalty slab is confined by the green dashed line in Fig. 2 at $\sim 950-1250 \mathrm{~km}$ depth, $\sim 910-1180 \mathrm{~km}$ depth and $\sim 860-$ $1100 \mathrm{~km}$ depth in the north, middle and south, respectively. To test this prediction we use mantle tomography to identify structures in the mantle beneath the Southwest Pacific that could represent the fossil slab.

\section{Southwest Pacific tomography models}

Tomographic imaging of the Earth's mantle has allowed detailed visualization of actively subducting slabs and detached slabs in the deep mantle. Figs. 4 and 5 illustrate the Southwest Pacific mantle

Fig. 3. Block diagrams illustrating the progressive migration of the New Caledonia subduction zone (in the Indo-Atlantic hotspot reference frame from Müller et al., 1993) and the progressive subduction, sinking and detachment of the South Loyalty slab. (a) Incipient subduction in the North. (b) Progressive subduction by slab rollback and southward growth of the subduction zone. At the northernmost part of the subduction zone (below the d'Entrecasteaux zone) a sub-vertical slab tear develops that allows for efficient slab-rollback-induced toroidal upper mantle return flow from behind the slab towards the mantle wedge, thereby facilitating rapid slab rollback at the northernmost part of the subduction zone. (c) Final stage of subduction in the north (New Caledonia region), with inception of slab detachment due to formation of a sub-horizontal slab tear that propagates southward. Subduction continues in the Norfolk-Northland region. (d) Continued southward propagation of the sub-horizontal slab tear. Active subduction is present only in the southernmost part (Northland region). (e) Slab detachment is now complete and the entire South Loyalty Basin slab is now located in the lowermost upper mantle and uppermost lower mantle. (f) Continued sinking of the South Loyalty Basin slab in the lower mantle. 


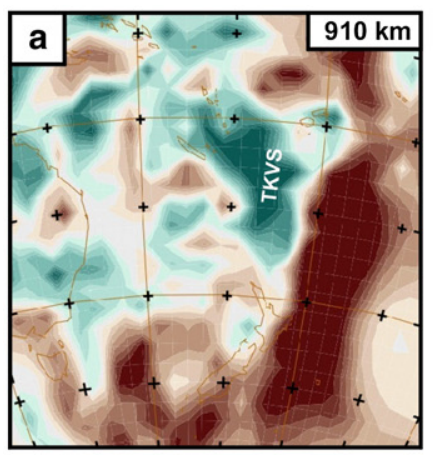

S-wave velocity perturbation $-1.5 \% \square+1.5 \%$

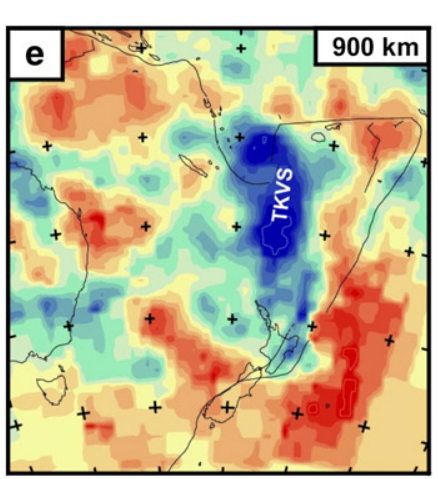

$X=0.9$
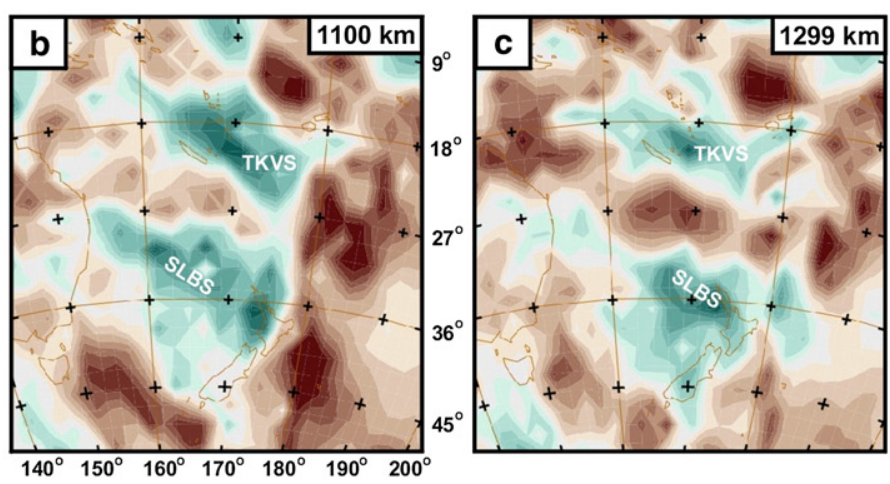

(40)

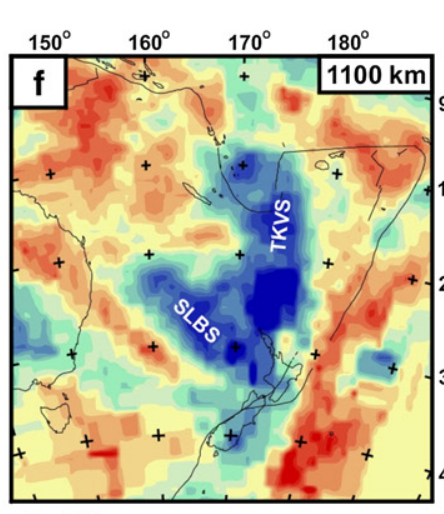

$X=0.6$

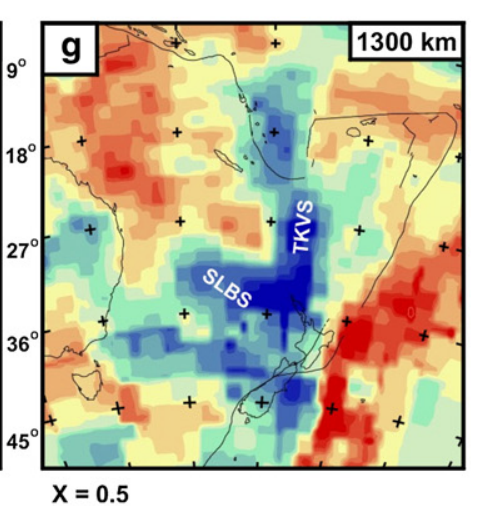

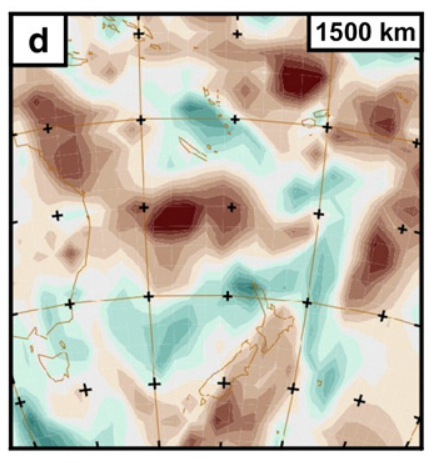

P-wave velocity perturbation $-\mathrm{X} \% \square+\mathrm{X} \%$

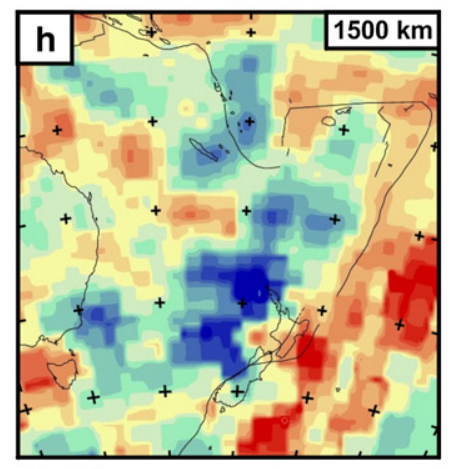

$X=0.5$

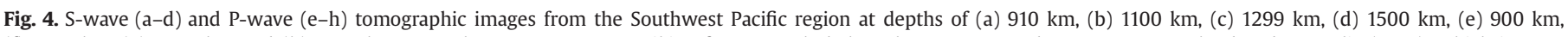

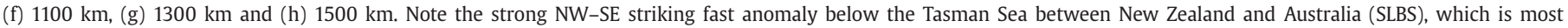

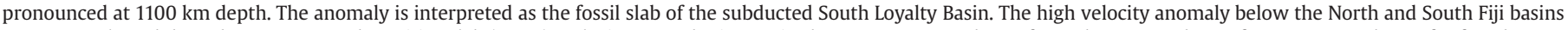

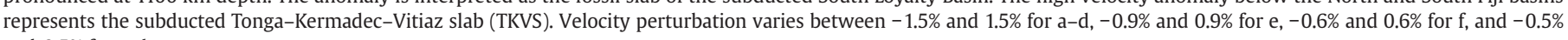
and $0.5 \%$ for $\mathrm{g}-\mathrm{h}$.

structure with a global S-wave model and P-wave model. Details on the S-wave model can be found elsewhere (Kennett and Gorbatov, 2004). The new global P-wave model P06 (Amaru, 2007) is based on a travel time data set that has approximately tripled in size compared to the data set used for an older model (BS2000, Bijwaard and Spakman, 2000). In particular, core phases have been incorporated to better constrain the lower mantle structure and the data set contains considerably more regional travel times.

The S-wave and P-wave models show high velocity anomalies at $900 \mathrm{~km}$ and $1100 \mathrm{~km}$ depth below the North and South Fiji basins, which represent the deep continuation of the Tonga-Kermadec-Vitiaz slab (van der Hilst, 1995; Hall and Spakman, 2002; Pysklywec et al., 2003). Indeed, the tomography models, in particular the P-wave model, show a northsouth striking high-velocity anomaly. This is in agreement with Cenozoic reconstruction models for the central and southern part of the Tonga-Kermadec-Vitiaz subduction zone (e.g. Hall and Spakman, 2002; Schellart et al., 2006; Sdrolias and Müller, 2006).

Of particular interest for this study is a pronounced fast NW-SE striking anomaly in the lower mantle below the Tasman Sea. The fast anomaly is best resolved at $1100 \mathrm{~km}$ depth (Fig. 4b,f) and has lateral dimensions of $\sim 2200 \mathrm{~km}$ by $\sim 600-900 \mathrm{~km}$. The high-velocity anomaly is less resolved at $1300 \mathrm{~km}$ depth, and disappears at 900 and $1500 \mathrm{~km}$ depth. Cross-sections shows that the anomaly is limited to a depth of $\sim 950-1350 \mathrm{~km}$ and is most pronounced at a depth of $\sim 1000-1200 \mathrm{~km}$ (Fig. 5). The S-wave anomaly has a higher amplitude than the P-wave anomaly, as generally observed for lower mantle slabs (Kennett and Gorbatov, 2004). The NW-SE striking high-velocity anomaly is situated in the predicted location to represent the fossil South Loyalty slab with the predicted NW-SE orientation and predicted lateral dimensions (Fig. 6).
The results from the S-wave tomography model and P-wave tomography model show a good agreement with respect to the geometry of velocity anomalies. For example, the cross-sections in Fig. 5 compare very well, both showing the flat-lying South Loyalty Basin slab at $1000-1200 \mathrm{~km}$, the upper mantle Kermadec slab, an apparent hole in the Kermadec slab, the potential lower mantle continuation of the Kermadec slab, and two pronounced low velocity zones, one above the South Loyalty Basin slab anomaly and one to the southeast of the Kermadec subduction zone. The fact that the two different models show such good agreement makes us confident that the South Loyalty Basin slab anomaly is well resolved.

Several other high-velocity anomalies are observed in Fig. 4. In particular, a high-velocity anomaly at $~ 900$ depth below the northeastern Australia-Coral Sea-New Guinea region (Fig. 4a and e) could represent fossil slab remnants related to Eocene-Oligocene subduction along the Pocklington subduction zone (e.g. Hall and Spakman, 2002; Schellart et al., 2006). The S-wave model and P-wave model also show a high-velocity anomaly below southeast Australia at $\sim 900 \mathrm{~km}$ depth. This anomaly remains visible in the P-wave model at $1100 \mathrm{~km}$ and $1300 \mathrm{~km}$ depth, with a WNW-ESE strike and extending towards the South Island of New Zealand. The amplitude of the anomaly, however, is rather small. For example, at $1300 \mathrm{~km}$ depth, it is only about $+0.20 \%$ with a range of +0.06 to $+0.31 \%$ in the P-wave model, while the S-wave model does not show a WNW-ESE striking feature. Thus, the anomaly might be insignificant.

\section{Resolution tests for tomography models}

Resolution tests for the P-wave model P06 have been conducted and are shown in Figs. 7 and 8. Fig. 7 shows results from spike 


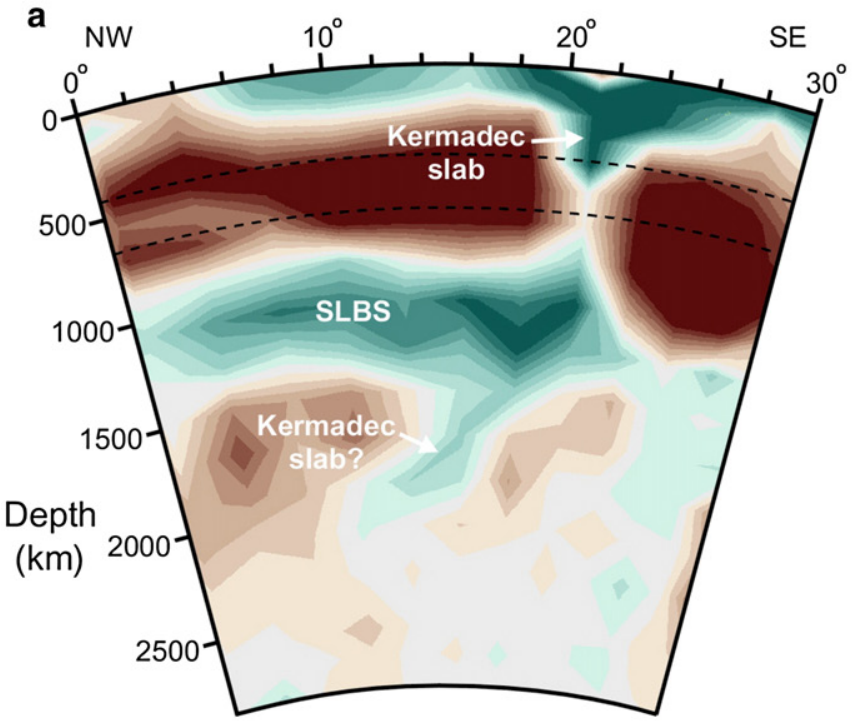

S-wave velocity perturbation

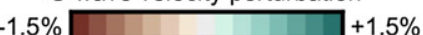

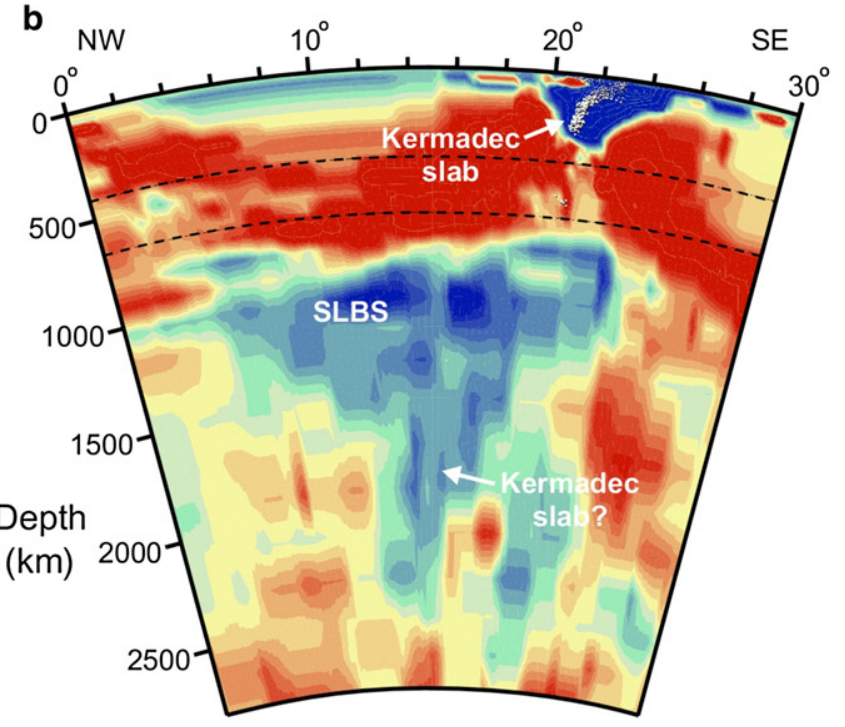

P-wave velocity perturbation

$-0.75 \% \square+0.75 \%$

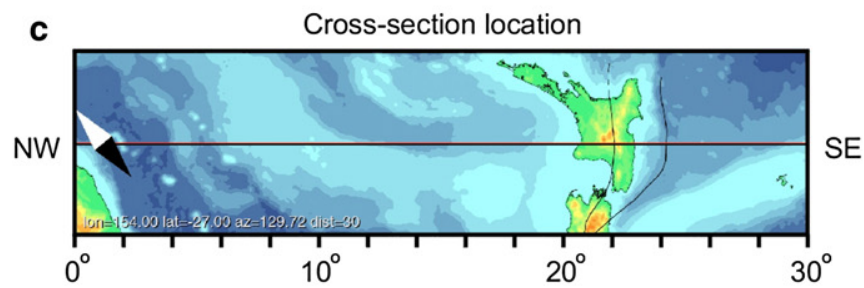

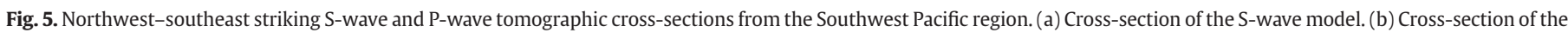

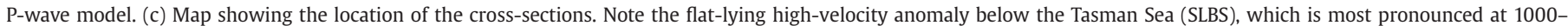

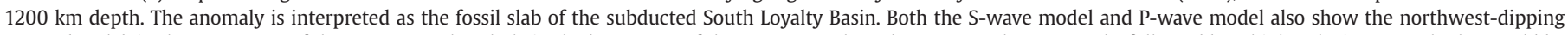

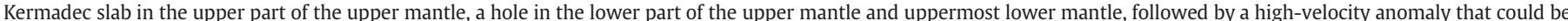

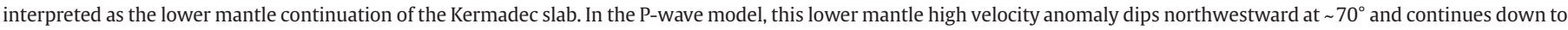
$\sim 2400 \mathrm{~km}$ depth. The hole could be due to insufficient ray coverage in that area. Note that the white lines in (b) mark $1 \%$ intervals.

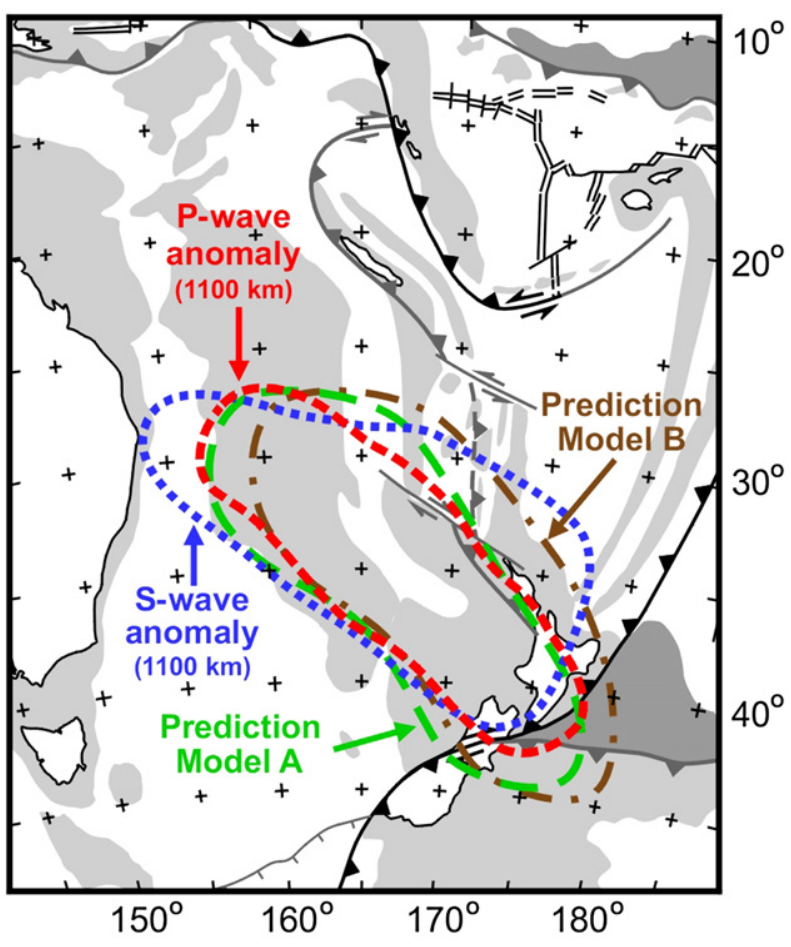

resolution tests. Spatially the spikes correspond well to their input locations and strong smearing effects along possible dominant ray directions do not occur. The spikes are recovered with reduced amplitude primarily as a result of the imposed smoothness constraints (damping) during tomographic inversion. We infer from this, and other sensitivity tests, that the imaged mantle structures shown in Fig. 4e-h are sufficiently resolved to identify the fossil South Loyalty slab.

Fig. 8 shows a synthetic slab test to investigate if the ray coverage in the region is sufficient to reproduce the South Loyalty slab at $1100 \mathrm{~km}$ depth and $1300 \mathrm{~km}$ depth. The test demonstrates that the outline of an anomaly of the assumed 3D shape of the South Loyalty slab can be imaged properly with only minor leakage to the surrounding mantle in both the horizontal direction (Fig. 8f and g) and vertical direction (Fig. 8e and h). This demonstrates the detectability of the bulk volume and its orientation. The overall amplitude recovery shows systematic underestimation of synthetic amplitudes, which relates to incomplete convergence of the LSQR algorithm from Paige and Saunders (1982) combined with applied damping. Particularly under New Zealand the test demonstrates lack of detectability of detailed structure within the synthetic anomaly. This results from the non-homogeneous sampling of this mantle

Fig. 6. Predicted location of the South Loyalty slab from the global (model in Fig. 2a) and Indo-Atlantic (model in Fig. 2b) hotspot reference frames, and the observed location of the S-wave anomaly and P-wave anomaly at $1100 \mathrm{~km}$ depth. 

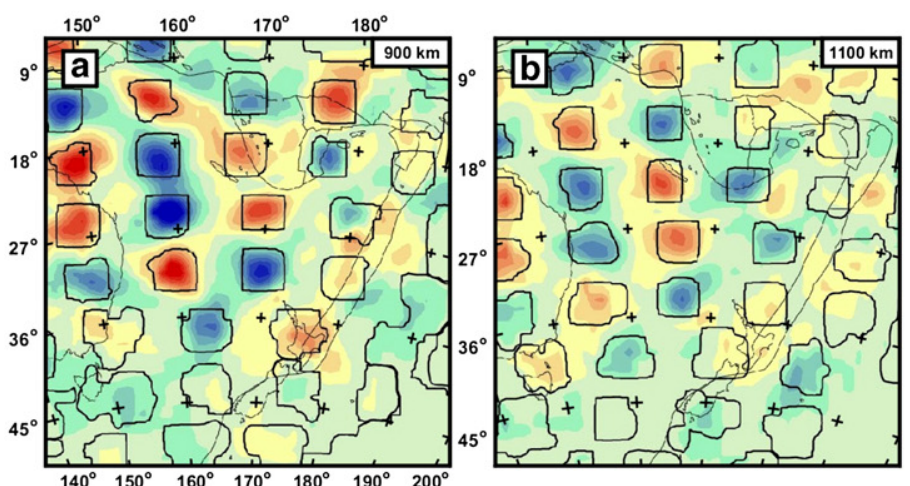
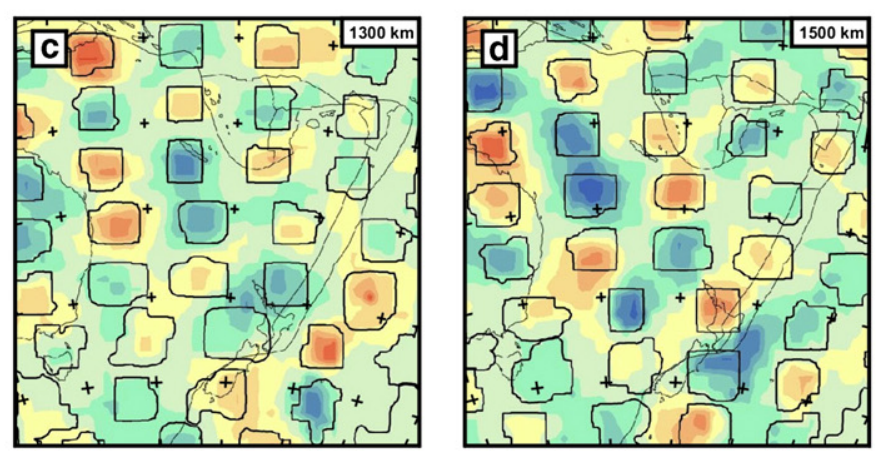

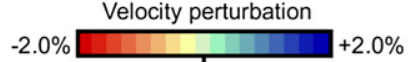

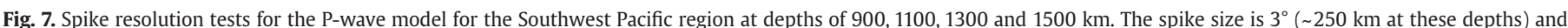

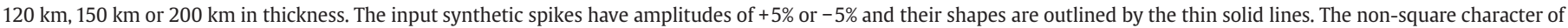

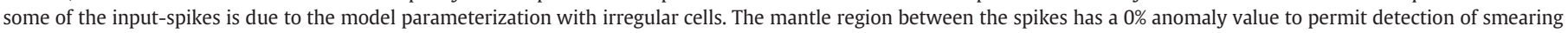

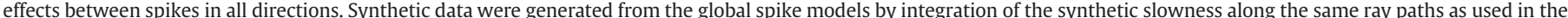

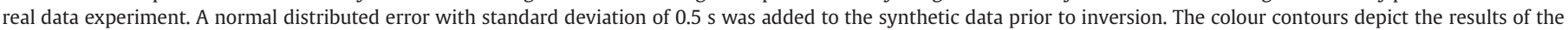

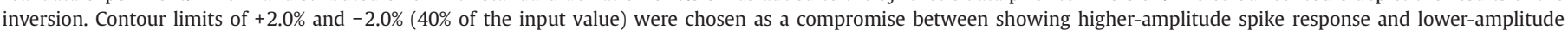

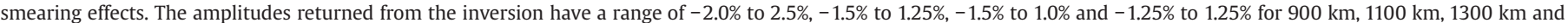
$1500 \mathrm{~km}$ depth, respectively.

volume, which locally affects convergence properties of the solution (Spakman and Nolet, 1988).

\section{Discussion}

\subsection{The South Loyalty fossil slab anomaly}

The continuity and sharp southwestern boundary of the SLBS anomaly as shown in Fig. 4b and f agree with the proposed model of a continuous $\sim 2500 \mathrm{~km}$ subduction zone, and negate earlier models involving two separate subduction zones for New Caledonia and Northland. Indeed, previous tectonic models involving a northeastdipping subduction zone in New Caledonia and a west or southwestdipping subduction zone in Northland would predict two small separate high-velocity anomalies rather than one continuous highvelocity anomaly as shown here. The sharp northwesternmost boundary of the anomaly, in particular for the P-wave model, implies
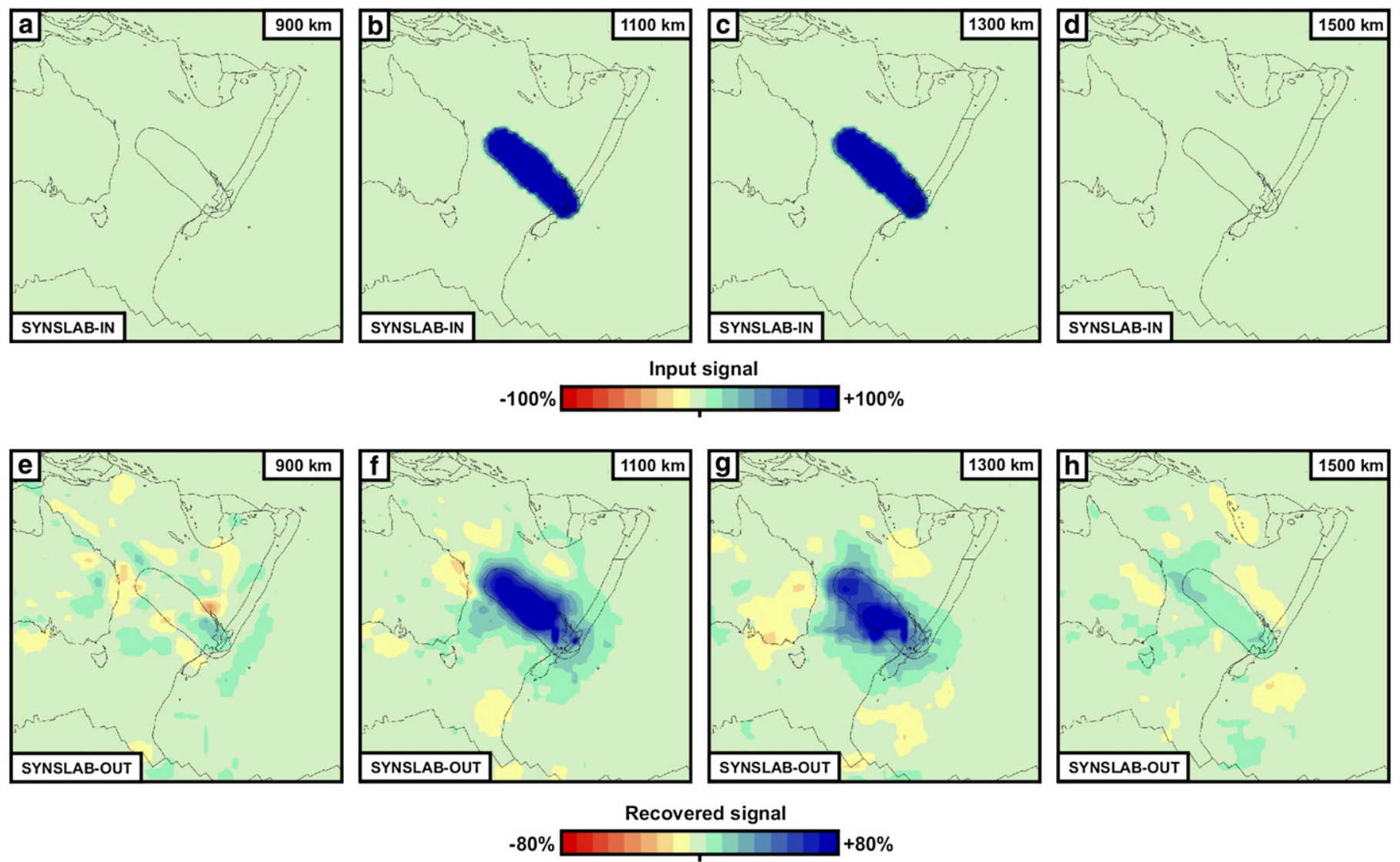

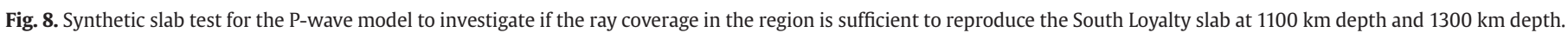
(a-d) Synthetic anomaly input of the assumed 3D shape of the South Loyalty slab at four depths. (e-h) Amplitude recovery at four depths. 
that the slab was indeed of limited trench-parallel extent, bounded on its northern side by the d'Entrecasteaux ridge, a fossil transform plate boundary. The d'Entrecasteaux ridge basically marks the surface expression of the fossil sub-vertical slab tear that migrated westward (Fig. 3b-c), conform the reconstructions from Schellart et al. (2006) and Schellart (2007), similar in function as the Hunter Fracture zone bounding the North Fiji Basin (e.g. Schellart et al., 2002) and conform a STEP fault as described in Govers and Wortel (2005).

The fast anomaly is best resolved at $\sim 1100 \mathrm{~km}$ depth (Fig. $4 \mathrm{~b}, \mathrm{f}$ ) and is situated in the predicted location to represent the fossil South Loyalty slab with the predicted NW-SE orientation and lateral dimensions ( $\sim 2200 \mathrm{~km}$ by $\sim 600-900 \mathrm{~km})$ (Fig. 6). Cross-sections shows that the anomaly is limited to a depth of $\sim 950-1350 \mathrm{~km}$ and is most pronounced at a depth of $\sim 1000-1200 \mathrm{~km}$ (Fig. 5), as predicted by the reconstructions and the average upper and lower mantle sinking velocities of $6 \mathrm{~cm} / \mathrm{yr}$ and $1.5 \mathrm{~cm} / \mathrm{yr}$, respectively. The P-wave model, and to a lesser extent the S-wave model, show that the southeastern extent of the South Loyalty anomaly abuts with the $\sim$ north-south striking Tonga-Kermadec-Vitiaz anomaly (Fig. 4f). This agrees with predictions from the regional reconstruction by Schellart et al. (2006), in which the opposite-dipping subduction zones were active contemporaneously, were widely separated in the north $(\sim 2000 \mathrm{~km})$, but were very close $(\sim 100 \mathrm{~km})$ at the southernmost extent of the New Caledonia subduction zone (southeastern Northland region).

\subsection{Sinking velocities for lower mantle slabs}

Fossil slabs have been recognized previously with tomographic imaging, including the Farallon slab underneath North America (Grand et al., 1997), the Mongol-Okhotsk slab underneath Siberia (Van der Voo et al., 1999), the Tethyan slabs underneath South Asia (Hafkenscheid et al., 2006), the fossil Gondwanaland margin slab underneath the Australian-Antarctic discordance (Gurnis and Müller, 2003) and the Vitiaz slab below the North Fiji Basin (Hall and Spakman, 2002; Pysklywec et al., 2003). The lower mantle free sinking velocity of $1.5 \mathrm{~cm} /$ yr for the South Loyalty slab is slower than that estimated for the Tethyan slabs ( $2 \mathrm{~cm} / \mathrm{yr}$; Hafkenscheid et al., 2006), but faster than the average mantle sinking velocity for the Mongol-Okhotsk slab $(1 \mathrm{~cm} / \mathrm{yr}$; Van der Voo et al., 1999). The Tethyan slab volumes are larger than the South Loyalty slab, thereby enhancing faster sinking. The lowermost part of the Mongol-Okhotsk slab appears to be resting on the core-mantle boundary, thereby partly supporting the trailing slab and retarding sinking. The South Loyalty slab is sinking freely, and thus a lower mantle sinking velocity of $1.5 \mathrm{~cm} / \mathrm{yr}$ appears realistic considering its rapid trench and subduction velocities ( $4-8 \mathrm{~cm} / \mathrm{yr}$ ).

\section{Conclusions}

Discovery of the fossil lower mantle slab solves a long-standing geological controversy related to the lateral continuity of the New Caledonia fossil subduction zone, polarity of subduction, source of middle Cenozoic magmatic rocks, and mode of ophiolite obduction. The fossil subduction zone ran from New Caledonia in the north to Northland in the south, stretching for some $2500 \mathrm{~km}$. The d'Entrecasteaux ridge functioned as a transform plate boundary (i.e. a STEP fault conform Govers and Wortel, 2005), and thereby represents the northern limit of the fossil subduction zone. The slab dipped northeast to eastward, and was responsible for arc volcanism along the d'Entrecaseaux-Loyalty-Three Kings-Northland Plateau seamount chain. In the final stage of subduction, the slab detached, causing detachment-induced magmatism and volcanism in New Caledonia, the Norfolk Basin and Northland (Schellart, 2007).

The discovery of the lower mantle slab necessitates an obduction mode in Northland and New Caledonia involving a subduction zone dipping away from the continental margin ( northeastward), which conforms the original theoretical obduction model from Moores
(1970) in which fore-arc ophiolites are obducted on top of a passive margin. The reconstructions predict a lower mantle slab sinking velocity of $\sim 1.5 \mathrm{~cm} / \mathrm{yr}$ and a lower mantle viscosity of $\sim 10^{22} \mathrm{~Pa} \cdot \mathrm{s}$. The considerable size of the subduction zone and fossil slab requires new models of global mantle circulation to incorporate this structure in future calculations.

\section{Acknowledgements}

Discussions with Tony Crawford, Sebastian Meffre and Nick Mortimer on Southwest Pacific geology and discussions with Rinus Wortel on slab detachment processes are greatly appreciated. Gerda Wesseling and Nina Schellart are thanked for providing a stimulating research environment in which the ideas outlined in this paper were developed. We thank Bruce Schaefer, Ross Griffiths, Dave Stegman, Randell Stephenson and Virginia Toy for comments on an early draft of the paper. We also thank an anonymous reviewer and reviewers Dietmar Müller and Trond Torsvik for their helpful comments. This work was supported by a Discovery grant and QE II Fellowship from the Australian Research Council and a J. G. Russell award from the Australian Academy of Science awarded to W.P.S.

\section{References}

Aitchison, J., Clarke, G.L., Meffre, S., Cluzel, D., 1995. Eocene arc-continent collision in New Caledonia and implications for regional southwest Pacific tectonic evolution. Geology 23, 161-164.

Amaru, M., 2007. Global travel time tomography with 3-D reference models. PhD Thesis, Utrecht University, Utrecht.

Baldwin, S.L., Rawling, T., Fitzgerald, P.G., 2007. Thermochronology of the New Caledonian high-pressure terrane: implications for middle Tertiary plate boundary processes in the southwest Pacific. In: Cloos, M., Carlson, W.D., Gilbert, M.C., Liou, J.G., Sorensen, S.S (Eds.), Convergent Margin Terranes and Associated Regions: A Tribute to W.G. Ernst. Geological Society of America Special Paper, pp. 117-134.

Bijwaard, H., Spakman, W., 2000. Non-linear global P-wave tomography by iterated linearized inversion. Geophys. J. Int. 141, 71-82.

Brothers, R.N., 1984. Subduction regression and oceanward migration of volcanism, North Island, New Zealand. Nature 309, 698-700.

Cloos, M., 1993. Lithospheric buoyancy and collisional orogenesis: subduction of oceanic plateaus, continental margins, island arcs, spreading ridges and seamounts. Geol. Soc. Am. Bull. 105, 715-737.

Cluzel, D., Aitchison, J.C., Picard, C., 2001. Tectonic accretion and underplating of mafic terranes in the late Eocene intraoceanic fore-arc of New Caledonia (Southwest Pacific): geodynamic implications. Tectonophysics 340, 23-59.

Crawford, A.J., Meffre, S., Symonds, P.A., 2003. 120 to 0 Ma tectonic evolution of the southwest Pacific and analogous geological evolution of the 600 to $220 \mathrm{Ma}$ Tasman fold belt system. Spec. Publ.-Geol. Soc. Aust. 22, 377-397.

Gordon, R.G., Jurdy, D.M., 1986. Cenozoic global plate motions. J. Geophys. Res. 91, 12389-12406.

Govers, R., Wortel, M.J.R., 2005. Lithosphere tearing at STEP faults: response to edges of subduction zones. Earth Planet. Sci. Lett. 236, 505-523.

Grand, S.P., van der Hilst, R.D., Widiyantoro, S., 1997. Global seismic tomography: a snapshot of convection in the Earth. GSA Today 7, 1-7.

Gurnis, M., Müller, R.D., 2003. Origin of the Australian-Antarctic discordance from an ancient slab and mantle wedge. Spec. Publ--Geol. Soc. Aust. 22, 417-429.

Hafkenscheid, E., Wortel, M.J.R., Spakman, W., 2006. Subduction history of the Tethyan region derived from seismic tomography and tectonic reconstructions. J. Geophys. Res. 111, B08401. doi:10.1029/2005JB003791.

Hall, R., Spakman, W., 2002. Subducted slabs beneath the eastern Indonesia-Tonga region; insights from tomography. Earth Planet. Sci. Lett. 201, 321-336.

Hayward, B.W., et al., 2001. K-Ar ages of Early Miocene arc-type volcanoes in northern New Zealand. N.Z. J. Geol. Geophys. 44, 285-311.

Herzer, R.H., 1995. Seismic stratigraphy of a buried volcanic arc, Northland, New Zealand and implications for Neogene subduction. Mar. Pet. Geol. 12, 511-531.

Kamp, P.J.J., 1984. Neogene and Quaternary extent and geometry of the subducted Pacific plate beneath North Island, New Zealand: implications for Kaikoura tectonics. Tectonophysics 108, 241-266.

Kennett, B.L.N., Gorbatov, A., 2004. Seismic heterogeneity in the mantle-strong shear wave signature of slabs from joint tomography. Phys. Earth Planet. Inter. 146, 87-100.

Kerr, R.C., Lister, J.R., 1991. The effects of shape on crystal settling and on the rheology of magmas. J. Geol. 99, 457-467.

Lithgow-Bertelloni, C., Richards, M.A., 1998. The dynamics of Cenozoic and Mesozoic plate motions. Rev. Geophys. 36, 27-78.

Malpas, J., Spörli, K.B., Black, P.M., Smith, I.E.M., 1992. Northland ophiolite, New Zealand, and implications for plate-tectonic evolution of the Southwest Pacific. Geology 20, 149-152.

Meffre, S., Crawford, A.J., Quilty, P.G., 2006. Arc-continent collision forming a large island between New Caledonia and New Zealand in the Oligocene. Australian Earth Science Convention. Geological Society of Australia, Melbourne, pp. 1-3. Extended Abstracts. 
Moores, E., 1970. Ultramafics and orogeny, with models of the US cordillera and the Tethys. Nature 228, 837-842.

Mortimer, N., et al., 2007. Oligocene-Miocene tectonic evolution of the South Fiji Basin and Northland Plateau, SW Pacific Ocean: evidence from petrology and dating of dredged rocks. Mar. Geol. 237, 1-24.

Müller, R.D., Royer, J.-Y., Lawver, L.A., 1993. Revised plate motions relative to the hotspots from combined Atlantic and Indian Ocean hotspot tracks. Geology 21, 275-278.

Paige, C.C., Saunders, M.A., 1982. LSQR: An algorithm for sparse linear equations and sparse least squares. ACM Trans. Math. Softw. 8 (1), 43-71.

Pysklywec, R.N., Mitrovica, J.X., Ishii, M., 2003. Mantle avalanche as a driving force for tectonic reorganization in the Southwest Pacific. Earth Planet. Sci. Lett. 209, 29-38.

Regnier, M., 1988. Lateral variation of upper mantle structure beneath New Caledonia determined from P-wave receiver function; evidence for a fossil subduction zone. Geophys. J. Int. 95, 561-577.

Schellart, W.P., 2005. Influence of the subducting plate velocity on the geometry of the slab and migration of the subduction hinge. Earth Planet. Sci. Lett. 231, 197-219.

Schellart, W.P., 2007. Northeastward subduction followed by slab detachment to explain ophiolite obduction and Early Miocene volcanism in Northland, New Zealand. Terra Nova 19, 211-218

Schellart, W.P., 2008. Kinematics and flow patterns in deep mantle and upper mantle subduction models: influence of the mantle depth and slab to mantle viscosity ratio. Geochem. Geophys. Geosyst. 9, Q03014. doi:10.1029/2007GC001656.

Schellart, W.P., Lister, G.S., Jessell, M.W., 2002. Analogue modelling of asymmetrical back-arc extension. J. Virtual Explor. 7, 25-42.
Schellart, W.P., Lister, G.S., Toy, V.G., 2006. A Late Cretaceous and Cenozoic reconstruction of the Southwest Pacific region: tectonics controlled by subduction and slab rollback processes. Earth-Sci. Rev. 76, 191-233.

Schellart, W.P., Freeman, J., Stegman, D.R., Moresi, L., May, D., 2007. Evolution and diversity of subduction zones controlled by slab width. Nature 446, 308-311. doi:10.1038/nature05615.

Sdrolias, M., Müller, R.D., 2006. Controls on back-arc basin formation. Geochem. Geophys. Geosyst. 7, 004016. doi:10.1029/2005GC001090.

Spakman, W., Nolet, G., 1988. Imaging algorithms, accuracy and resolution in delay time tomography. In: Vlaar, N.J., Nolet, G., Wortel, M.J.R., Cloetingh, S.A.P.L. (Eds.), Mathematical Geophysics: A Survey of Recent Developments in Seismology and Geodynamics. Reidel, Dordrecht, pp. 155-188.

Spandler, C., Rubatto, D., Hermann, J., 2005. Late Cretaceous-Tertiary tectonics of the southwest Pacific: insights from U-Pb sensitive, high-resolution ion microprobe (SHRIMP) dating of eclogite facies rocks from New Caledonia. Tectonics 24, TC3003. doi:10.1029/2004TC001709.

van der Hilst, R.D., 1995. Complex morphology of subducted lithosphere in the mantle beneath the Tonga trench. Nature 374, 154-157.

Van der Voo, R., Spakman, W., Bijwaard, H., 1999. Mesozoic subducted slabs under Siberia. Nature 397, 246-249.

Whattam, S.A., Malpas, J.G., Ali, J.R., Smith, I.E.M., Lo, C.-H., 2004. Origin of the Northland ophiolite, northern New Zealand: discussion of new data and reassessment of the model. N.Z. J. Geol. Geophys. 47, 383-389.

Wortel, M.J.R., Spakman, W., 2000. Subduction and slab detachment in the Mediterranean-Carpathian region. Science 290, 1910-1917. 